\title{
The Genealogy of Personality Psychology - Why Personality Became So Important
}

\author{
Sven Hroar Klempe \\ Department of Psychology, Norwegian University of Science and Technology (NTNU), Trond- \\ heim, Norway
}

*Corresponding author. Email: hroar.klempe@ntnu.no

Background. Personality psychology in academia reached its peak in Western psychology in the 1960s and 1970s. Its history usually starts with Freud and ends up with the Big Five. Yet its roots go much deeper, and can be traced back to the early use of the term "psychology", primarily among Protestant scholastics in the late sixteenth century. This was related to the Christian Reformation, which highlighted the sacrament of penance and emphasized self-examination of the true believer. The background for this study is to bring in a historical perspective on personality. Max Weber, for example, demonstrated that this led to a morality of faithfulness to one's deeds. This duty, he says, explains the prosperity of the Protestants in Europe and the US in the seventeenth century. Michel Foucault showed in the first volume of The History of Sexuality how the sacrament of penance led to a certain interest in human nature and sexuality. Human nature was at the core of the very early use of psychology.

Objective. The objective of this paper is to focus on how these aspects were treated in early psychology by following a design that examines the person, human nature, individual differences, and intellectual abilities.

Results. One of the results is that there is a direct connection between the use of the term "personality" in psychology, and the use of the term "psychology" from the very beginning based on the following findings: (a) "Psychology" appears in the wake of the interest in the individual, and (b) "Personality" appears as a specified term with the aim of achieving a scientific understanding of individuality.

Conclusion. Thus, one conclusion is that we have definitely not solved the dilemma that Gordon Allport pointed to: that traditional scientific ideals deal with general laws, whereas personality psychology deals with individuality. Another important conclusion is that this dilemma and conflict are not possible to solve within psychology.

\section{Keywords:}

personality

psychology,

history of

personality

psychology,

history of

psychology,

individual

psychology,

human nature 


\section{Introduction}

Like many other terms in psychology, "personality" is a term that may point in different directions. It reflects in many ways the main perspective and focus that characterize the psychology of the twentieth century. The term "personality" can be related to almost all the schools and orientations that dominated the field in the twentieth century - from psychoanalysis to behaviourism; it can be covered by the century's methodological diversity, ranging from narrative self-reporting to quantitative systematization. It is a term that was almost unavoidable from the 1930s to the 1970s, but before and after this period, the term was used less. It is an intriguing question, why and how this term became so important and popular for a while, but also why it was not much used in certain other periods.

In this paper, I will pursue how personality became an important term in psychology by focusing on two historical aspects: how the term developed in the twentieth century, and how that compares with the time that the term "psychology" appeared in European languages for the first time. There is a strong connection between the two, as the most fundamental question related to this term is the relationship between the general understanding of human nature and individual diversity. This is the conflict that Gordon Allport (1960) identified. Indeed, the most radical conflict between those two aspects of the psychological human being can be traced back to the sixteenth century. I will start with how the term appeared and was conceived during the twentieth century.

\section{Psychological Terms}

Terms in psychology have never been stable, yet there are two aspects that may characterize the appearance of psychological terminology. Most of the terms have their origin in well-established everyday words, which are turned into a more specialized use. Other terms may have the opposite origin, namely that they are construed to depict certain psychological phenomena, and then become adopted by everyday language. The terms "passion" and "emotion" may exemplify these origins.

"Passion" was a word that was used in everyday English in the seventeenth century. When the British empiricists started investigating human nature, the general term they used for feelings was "passions". Thomas Hobbes and John Locke never used the word "emotion", but they both referred to "passion" as the general term (Richards, 1989). Even David Hume, a hundred years later, uses "passion" in his titles when he discusses feelings and human nature; however, in his text, he gradually introduces "emotion" as a general term. The difference between the two terms is very much related to the scientific and philosophical changes in perspectives about humans during the Enlightenment. Descartes had become popular by, among other things, describing human nature and its passions in purely mechanistic terms (Descartes, 2015 version). But the term "passion" may have negative connotations, including moralistic overtones, and therefore did not fit the ideals that lie behind a more mechanistic understanding of human nature. "Emotion", which just refers to the fact that one is moved by something, represents a more neutral understanding of these aspects of human nature, and this term was therefore gradually adopted as a more scientific term for describing feelings in general. This term, which started 
as a rather specialized term, was later applied in everyday language, of which it is a normal part today.

The term "personality", on the other hand, is comparable with both types of origin. As Kurt Danziger (1997) points out in his brilliant analysis of the term, it was in use long before psychologists adopted it. When it appeared in psychology, the meaning went in two different directions. One was medical, referring to diseases related to personality, and consequently, the term became associated with alternating personality or multiple personality. The other direction was the selfimprovement literature, which, according to Anthony Gidddens (1991), is one of the main characteristics of late Western modernity. This type of literature had existed for a while before the twentieth century, although it did not use the term "personality", but rather the more common word in everyday-language, "character". According to Danziger, this ended up in a broad understanding of the term, which covered both some medical aspects and the core of a modern individual's everyday life: "Not only had 'personality' become a part of the individual that had to be watched anxiously for signs of disease, it had also become a universal possession capable of degrees of perfection defined in terms of a vocabulary of social effectiveness" (Danziger, 1997, p. 125). The most important aspect of the use of the term "personality", however, was that it was conceived as a quite neutral term, and therefore was a very welcome replacement for the term "character", which was, and still is, strongly associated with morality, as we always connect character to something that is good or bad.

\section{Personality and Individuality}

Personality is particularly associated with individuality. Many associate this aspect with French psychologist Alfred Binet, who coined the term "individual psychology", as well as with Francis Galton and William Stern, who both focused on individual differences in a systematic way. These aspects bring us to the core of what the term "personality" and personality psychology are supposed to be about. Personality tries to capture individuality, which is also the core of psychology.

Gordon Allport, probably the most important contributor to the development of personality psychology, was very conscious of the importance of individuality. He saw that there is an almost insurmountable conflict between traditional scientific ideals, which deal with general laws, and personality psychology. When psychological research tries to follow scientific ideals by achieving general laws, Allport says it will "assume that the individual must be brushed aside" (Allport, 1960 , p. 11). He continues very wisely by saying, "This tradition has resulted in the creation of a vast shadowy abstraction in psychology called the generalized-adulthuman-mind" (p. 12). This abstraction not only challenges, but also violates the idea of the individual. Moreover, the individual is not to be regarded as a stable entity, as even the adult mind develops. Allport compares psychologists and literary writers, and concludes that the latter are better able to grasp the individuality of a person than the psychologists. "The abstraction that the psychologist commits in measuring and explaining a non-existent mind-in-general is an abstraction that no literary writer ever commits" (Allport 1960, p. 12). Neither Allport nor most other psychologists will give up the idea of understanding the individual, however, 
and Allport concludes that the dilemma appears inexorable and therefore impossible to avoid.

The challenge is predominantly embedded in terms and how they are applied. This becomes evident by looking at the transition from use of the term "character" to that of the term "personality" instead. This is a transition of perspectives as well. The former might be associated with morality, in the sense that character can be good or bad. Although one may think of personality as being good or bad in everyday life, this can be avoided when it is applied as a specialized term. This was of course achieved by developing personality-measurement instruments. The various personality tests measure the strengths and weaknesses of a person, rather than their good and bad sides. The moral aspects are not necessarily included when we refer to strengths and weaknesses, only the person's capacity for doing the job or not. Strengths and weaknesses just tell us in which areas a person does or does not have competences and skills. This way of looking at a person is devoid of moralistic judgements; it is rather a sober assessment, and consequently also a neutral conclusion. On this basis, the term "personality" satisfies the scientific ideal of measuring some general qualities of a person.

\section{Personality and the Self}

On the other hand, we are still dealing with the problem that Allport identified, specifically a "generalized-adult-human-mind". On this background, a third term appeared to replace "personality", and that was the term "self". Allport had problems with accepting a personality as being just one thing, and therefore used the term "trait", which indicates that a personality may include tendencies related to different types of personalities. Thus an individual's personality can never be depicted by just one "generalized-adult-human-mind"-type, but by several and maybe even different types of "generalized-adult-human-minds". Another aspect is that a human being lives a life whose main characteristic is development. Development is not just about how a child turns into an adult, but is also an important aspect of adulthood.

Development through the whole life-span has just recently become a focus in Western psychology; however, in Russian psychology it has been covered by the more or less well-established term "Achmeology", coined by B.B. Rubnikov in 1928 (Chvojková, 2013), and later adopted by B. G. Ananiev (Mironenko, 2013). This term is completely unknown in Western Europe and the US. According to this concept and recent research in Western countries, the life-span must be regarded as a developing process, in which numerous aspects contribute to form an individual's personality. This implies that the personality itself must reflect a corresponding complexity, which is able to absorb all the constituting factors in a person's life. As a consequence, the term "self" has more or less been applied to replace "personality", quite simply because it is diffuse enough to be filled up with different types of elements that may reflect the complexity of an individual's mind.

On this background, many different types of self-psychology have appeared. One theory with great impact in the 1970s was Heinz Kohut's self-psychology, in which the self was divided into three "poles". One pole is the grandiose-exhibitionistic self; another is the idealized self, in terms of the need for an omnipotent, 
idealized figure; the third pole reflects the need to project oneself onto an alter-ego, which is the search for a twin in the self ("Twinship", Kohut, 1984/2013). In the psychoanalytic tradition, the challenge has been to describe and model the complex dynamics that evolve among the different parts of the self, primarily based on the conflicts that may appear among them. Yet the self can represent a multiplicity, which is not necessarily based on conflicts. This is the self that may appear within a narrative framework, which is more about the different roles that an individual may play in life. This was first described by Erwing Goffman (1959), but has been followed up by narrative approaches like that of D. P. McAdams in his book The Stories We Live By (1993). Although an individual's life may change and produce different stories, "a fundamental aspect of selfhood is the process of integrating, unifying, [and] synthesising the disparate elements" (Wollmer, 2007, p. 31). In this respect, the understanding of the narrative self is different from the psychoanalytic understanding of the self, as it underlines unifying processes instead of conflicting ones. The dialogical self, on the other hand, may count as a third alternative, as it is based on L. S. Vygotsky's thesis of inner speech and M. M. Bakhtin's idea of the polyphonic mind. This theory includes the aspect of conflict, but due to its dialectic basis, it also includes mediation, the synthesis that unites the thesis and the antithesis.

\section{Character, Personality, and Self Compared}

With all these different theories about the self, the term itself has become quite widespread, and we see a clear movement in the historical development of terms to depict an individual, from use of the term "character" at the beginning of the twentieth century, via "personality", to end up with the dominance of "self" at the end of the twentieth century. A meta-study (Teigen, Normann, Bjørkheim, \& Helland, 2000) on the use of the three terms in scientific publications in psychology during the twentieth century demonstrates this development from a historical perspective. This is presented in Figure 1.

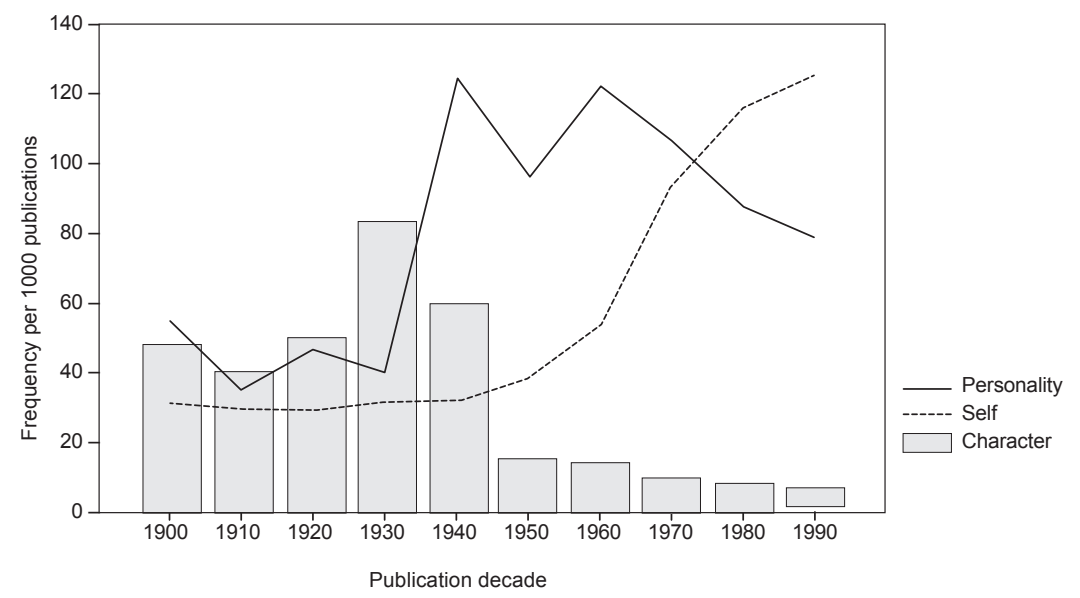

Figure 1. Increase and decrease of use of the terms "personality", "self", and "character" (Teigen et al., 2000, p. 22). 
Any discussion of the use of these three terms is closely related to a question about identity: To what extent is a person still the same after having developed and changed continuously throughout life? This is a fundamental logical problem that scholars have dealt with for centuries, and it is still embedded in the use of "personality" and its adjacent terms. This logical puzzle was explicitly addressed in the seventeenth and eighteenth centuries, and one of those who tried to figure out how it could be solved was John Locke. He simplifies the question by asking rhetorically whether a man wearing one set of clothes one day, and another set of clothes another day, should therefore be two different persons. His answer is related to the use of the term "consciousness", which was completely new in English at that time, and he regarded it to be the unifying term to describe a person. The point he makes is that we have to make a distinction between substances and consciousness. When we are thinking about something, we are thinking about substances. Thus consciousness might be filled up with different substances, in the same way as we are wearing different clothes, but they are still united by the same consciousness. "For the same consciousness being preserved, whether in the same or different substances, the personal identity is preserved" (Locke, 1651/2014, Book II, Ch. 27, p. 14).

\section{The Appearance of Psychology and Theology}

The discussion Locke is dealing with here is very much related to the big changes that took place in European culture during the Enlightenment. In the same period, "psychology" also appeared as a term. This was the time when the term "consciousness" replaced the term "mind", which also had replaced the term "soul" a hundred years earlier. In other words, this was a time of transitions and changes. The appearance of psychology was a crucial factor in many aspects of the transitions that happened at that time, as the greatest turmoil that occurred was when subjectivity emerged as a central part of philosophy.

This was the point of departure for Immanuel Kant when he wrote the Critique of Pure Reason. In his thesis, subjectivity formed the foundation for establishing a completely new type of objective knowledge. This change of perspective was what he called a Copernican revolution in philosophy, in which objective knowledge was no longer based on objective and general tenets about the outer world, but on a subject's inner cognitive capacity. This is transcendental philosophy, in which subjectivity forms the basis for universal and objective knowledge.

This would not have happened if psychology had not appeared as an independent subject in the academic arena. Consequently, it is not sufficient to explain interest in the individual's personality by just referring to this turn and the changes in philosophy. Its roots go far deeper, and "psychology" as an emerging academic discipline can be traced back to the early use of the term back in the early sixteenth century. The term "person" can be traced much further back in history. In the sixteenth century, both terms had Greek origins and they were both used in theology. In Catholic theology, Thomas Aquinas made a distinction between an individual and a person, in the sense that a person was a complete, rational individual, a state which was only fully achieved through participation in Holy Communion (Clarke, 1992). The early use of the term "psychology" is partly comparable to the Catholic use of the term "person", but the former appeared primarily among Protestant 
scholastics in the late sixteenth century. The term "psychology", therefore, was related to the Reformation, which highlighted the sacrament of penance, emphasizing the self-examination of the true believer.

According to Max Weber, this sacrament led to a morality of being faithful to one's deeds. This duty, he says, explains the prosperity of the Protestants in Europe and the US in the seventeenth century (Weber, 2011 version) In the Catholic Church, the Counter Reformation also highlighted this sacrament, and Michel Foucault has demonstrated how the sacrament of penance led to a certain interest in human nature and sexuality (Foucault, 2013). Focus on human nature was at the core of the rise of psychology as an independent academic discipline from the very beginning. This interest was central primarily for the Protestants, and one of the most important figures in this was Philipp Melanchthon, who wrote papers and gave lectures on Aristotle's De Anima, but expanded the content to include physiological aspects of the person. He revitalized Galen's thesis of the four humours, related to different fluids in the body, and by this made a direct connection between the soul and the body.

On this basis, there is a close connection between the Catholic conception of a person and the Protestant conception of psychology. Both are related to the holy sacraments, and both emphasize individuality. Yet the differences are just as interesting. The sacrament of Communion underlines the aspect of being a part of a community, which is of a general order, whereas the sacrament of penance is about confessing sins that the individual alone has committed, which is of an individual order. Hence, by merging person and psychology, there was already at the beginning an embedded conflict, which is comparable with the paradox Allport pointed to when he referred to a non-existent mind-in-general. This is the classical conflict between the general and the particular.

\section{The Term 'Person'}

This may also be an important aspect of the term "person". The original meaning of the word is related to the theatre in ancient Greece, and later on in Rome, where the actors used masks. The term "person" is usually explained as if it originally referred to a mask (Allport, 1937). However, the etymology of the term is more uncertain.

One version, which is regarded as the most accepted, says the term is a compression of the Latin phrase per sonare, which means "to sound through" (Allport, 1937). "According to this theory the term had reference to a large mouth of the mask", says Allport (1937, p. 26). However, this meaning can be related to another perspective, which does not focus so much on visual properties. When masks were used, the mask itself had a specified and fixed expression. This made masks that featured general characters; however, the individuality of the character was transmitted through the voice of the actor. Consequently, when actors donned masks in the ancient theatre, the voice - one of the most sensorial forms of communication - was the only thing that conveyed individuality. Thus in ancient Greek and Roman theatre, there were two layers of information about the character: the general provided by the mask, and the particular provided by the voice. General knowledge about the character was highly valued, as it made the 
character predictable. The intonation of the voice, on the other hand, appeared as unpredictable, as it could be gentle in one second and harsh in another. General knowledge has always been appreciated, whereas unpredictable knowledge based on experience has always had a lower status. This is reflected in Aristotle's thesis in De Anima, which is about how knowledge is acquired. What characterizes this thesis, however, is that knowledge acquired through experience is accepted as a necessary and unavoidable starting point, but the knowledge that counts is that processed by thinking. Thus, Aristotle's thesis is not about psychology, but about the theory of knowledge. From a psychological perspective, on the other hand, a person has always been regarded as a sensorial entity.

\section{Two Historical Needs for Psychology}

Theology and philosophy found each other in focusing on general knowledge during medieval times. This changed radically in the Renaissance. There were, however, two different and apparently contradictory movements that took place. One was the movement of humanism, which was sceptical toward the institutionalized Church, and rather emphasized individual honesty in faith. This culminated in Protestantism. The other was the divorce between theology and philosophy. This was a consequence of the Protestants' slogan "Scripture alone", which indicated that there were no room for philosophy in theology. This resulted in the fact that philosophers had to search for a secular basis for philosophy.

It was in the wake of these two tendencies that the term "psychology" appeared in the sixteenth century, primarily among Protestant scholastics (Vidal, 2011). The two movements resulted in a common interest in human nature. The Protestants wanted to know more about human nature because they focused so heavily on the sacrament of penance, and secular philosophy, because the subject appeared to be the only basis for philosophical knowledge when God did not count as a basis for knowledge about the secular world. Descartes, among others, demonstrated that secular philosophy called for a deeper understanding of the person that thinks, and of that person's nature.

There are about three known appearances of the term "psychology" in the sixteenth century. The first is traced back to the Croatian humanist Marko Marulić (1450-1524). He wrote in Latin, and his thesis about the soul was entitled: "Psichiologia de ratione animae humanae" ("Psychology, the nature of the human soul"). We know only the title, as the manuscript has been lost.

The second was the German philosopher Johann Thomas Freigius (1543-1583), who was a so-called Raminist, which means that he taught a free understanding of Aristotle's logic. Typical for the Raminists was to state that it is difficult to make a clear distinction between inductive and deductive inferences. This opened the way for the belief that an inference that started with the particular could be just as valid as an inference that started with the general. This was an attack on Aristotelian philosophy, and opened up the way for psychology. Aristotle never accepted sensory experiences as the basis for scientific knowledge, whereas these are at the core as psychological factors. Freigius was the one who placed psychology within philosophy, along with those sciences that were based on sensory experiences, like physics, astronomy, and the like. Another important thing he did, was to place 
those sciences on the same level as metaphysics (Luccio, 2013). Freigius did not use the word "psychology" in book titles, but he treated the topic in his writings of the 1570s, and both aspects pointed at here formed the foundation of a secular philosophy based on psychological factors.

The third person we know who used the term "psychology" and gave it content is the German philosopher Rudolph Goclenius the Elder (1547-1628) (Krstic, 1964), who published in 1590 a thesis in which "Yuchologia" ("Psychology") formed the key term. The full title indicates that it focuses on the perfection of the human soul, but at the same time, it presents some theological and philosophical arguments relevant to "our age" ("nostra aetetis"). One of the hot topics of discussion at that time was how to understand Original Sin: Is the soul, and therefore also sin, inherited directly from our ancestors (traducianism), or is the soul created individually for each person (creationism)? The latter perspective won out, and formed one of many premises for looking at human beings as individuals.

Another important factor that completely changed the understanding of the human being was the changes in the understanding of the soul. In ancient times, this was divided into its immortal aspects and its intellectual abilities. However, when philosophy merged with theology in the early Middle Ages, this distinction disappeared. It was allegedly the Church Father Isidor of Sevilla who in the seventh century decided that there should not be such a distinction. This underlined the collectivistic thinking in the Catholic Church: Differences in intellectual capacities should not count in the salvation of the soul. The revolt in the Renaissance was very much directed towards this levelling of individual differences. The ancient perspective on the soul was evoked again, and this created the basis for the faculty psychology as a discipline in the eighteenth century. A focus on human faculties still forms the basis for talking about personal differences in intellectual abilities. There was, in other words, a complete reorientation in how to understand human beings, a turn away from a general and collectivistic understanding to a focus on individual differences. The emergence of psychology as an academic discipline can be regarded as a driving force in this process.

\section{Conclusions}

We may conclude that there is a direct connection between the use of the term "personality" in psychology, and the use of the term "psychology" from the very beginning. However, the very beginning refers to the sixteenth and the seventeenth centuries. This implies that Aristotle's De Anima is not regarded as a central part of the history of psychology, as his thesis is predominantly about philosophy. The difference, however, is that philosophy proceeds from the need to acquire general knowledge of universal validity, whereas psychology proceeds from the opposite, the need to acquire specific knowledge of particularities. The latter includes human beings in a double sense: First, our sensory system deals with particularities through sensation, in contrast to the higher mental functions like language and thinking, which deal with the general and with generalized meanings. Second, by emphasizing the sensorial aspects that are entrenched in the body, the individual appears as unique, but also as a multifarious and rich entity by itself. This is what Europe discovered in the Renaissance and the Enlightenment. 
According to Allport (1960) the first biography we know about was published in 1683 . Yet before that, an expression already existed, which became highly appreciated in nineteenth-century Romanticism, and this was the phrase "individuum est ineffabile": The individual is unlimited and inexpressible. This was Goethe's slogan when he started pursuing just one character in his novels, like The Sorrows of Young Werther from 1774. Wilhelm Dilthey referred to this when he tried to explain hermeneutics (Dilthey, 1900).

These cases represented a complete change of perspective, which was definitely comparable with the Copernican revolution. While Kant realized that this turmoil also occurred in philosophy, it was actually not Kant who introduced subjectivity in philosophy, although most textbooks say he did. It was rather Christian Wolff, who had included Psychologia empirica as a part of metaphysics along with ontology, cosmology, rational psychology, and natural theology in 1732. The British empiricists also contributed to this when they focused on human nature in their philosophical writings, although they never used the term "psychology". They did not have to, because psychology had already intervened in philosophy when Freigius and Goclenius used the term in the latter part of the sixteenth century.

From this perspective, it was completely appropriate when Allport, in a tone of resignation, concluded that there is a fundamental dilemma embedded in personality psychology, and that this dilemma is unavoidable. Although we want to grasp the individual with the term "personality", our scientific ideals go relentlessly in another direction. Even in psychology, too many are still following Kant's ideal from the Critique of Pure Reason, which says that only general statements are acceptable from a scientific point of view. Although he banned psychologia empirica from metaphysics, many approaches in psychology, and not least research in personality psychology, still follow such ideals of pure science. As long as this is the case, the result is exactly what Allport saw in the 1950s, namely that "[ $t$ ]his tradition has resulted in the creation of a vast shadowy abstraction in psychology called the generalized-adult-human-mind" (Allport 1960, p. 12). Although Aristotle's logic was already challenged in the early Renaissance, it is hard to see how a specific understanding can turn out to be generally valid. And if not, just the aim to acquire general knowledge about personalities has to end up with abstractions and a non-existent generalized-adult-human-mind. To avoid this, and to say something about the individual personality, personality psychology has to apply methods and approaches that focus on the specificity of an individual, which was something that Gordon Allport saw and realized.

\section{References}

Allport, G.W. (1937). Personality. A psychological interpretation. New York: Henry Holt and Company.

Allport, G.W. (1960). Personality and social encounter. Selected essays. Boston, MA: Beacon Press. Chvojková, P. (2013). Akmeology - The science of reaching the top. PsychoLogOn, 2(1), 82-83. Retrieved on 30 Nov. 2018. Available at: http://psychologon.cz/component/content/ article/14-psycholog-online/413-akmeology-the-science-of-reaching-the-top

Clarke, W.N. (1992). Person, being and St. Thomas. International Catholic Review, 19(4), 601618. 
Danziger, K. (1997). Naming the mind. How psychology found its language, London: Sage.

Descartes, R. (2015 version). The passion of the soul and other late philosophical writings. Oxford: Oxford University Press.

Dilthey, W. (1900). Die Entstehung der Hermeneutik. Verlag J.C.B. Mohr (Paul Siebeck). https://archive.org/details/bub_gb_icZZAAAAcAAJ

Foucault, M. (2013). History of sexuality. The will to knowledge, Vol. 1. Translated by M.G.E. Kelly. Edinburgh: Edinburgh University Press.

Gidddens, A. (1991). Modernity and self-identity. Self and society in the late modern age, Cambridge, UK: Polity Press

Goffman, E. (1959). The presentation of self in everyday life. Garden City, NY: Doubleday Anchor Books.

Krstic, K. (1964). Marko Marulic - The author of the term "Psychology", Acta Instituti Psychologici Universitatis Zagrabiensis, No. 36, 7-13. Retrieved from http://psychclassics.yorku.ca/Krstic/marulic.htm

Kohut, H. (1984/2013). How does fnalysis cure? Chicago, The University of Chicago Press. https:// doi.org/10.7208/chicago/9780226006147.001.0001

Locke, J. (1651/2014). An essay concerning human understanding. Hertfordshire, UK: Wordsworth.

Luccio, R. (2013). Psychologia. The birth of a new scientific context. Review of Psychology, 20(1-2), 5-14.

McAdams, D.P. (1993). The stories we live by. New York: Guilford Press.

Mironenko, I. (2013). Contemporary Russian psychology in the context of international science. Procedia - Social and Behavioral Sciences, 86, 156-161.

Teigen, K.H, Normann, H.-T. E., Bjørkheim, J.O., \& Helland, S. (2000). Who would you most like to be like? Adolescents' ideals at the beginning and the end of the century. Scandinavian Journal of Educational Research, 44(1), 5-22. https://doi.org/10.1080/713696661

Vidal, F. (2011). The sciences of the soul. The early modern origins of psychology. Translated by S. Brown. Chicago: The University of Chicago Press. https:// doi.org/10.7208/chicago/9780226855882.001.0001

Vollmer, F. (2007). The self. Bergen: Fagbokforlaget.

Weber, M. (2011). The Protestant ethic and the spirit of capitalism. Translated by S. Kalberg. New York: Oxford University Press.

Original manuscript received January 18, 2019

Revised manuscript accepted March 04, 2019

First published online June 15, 2019

To cite this article: Klempe, S.H. (2019). The Genealogy of Personality Psychology - Why Personality Became So Important. Psychology in Russia: State of the Art, 12(2), 58-68. DOI: 10.11621/pir.2019.0205 